\title{
The Dynamics of Listed SMEs in China
}

\author{
Jia Liu
}

\begin{abstract}
We examine the dynamics of Chinese listed SMEs with respect to their post-market viability and growth after going public. The Kaplan-Meier estimation shows that SMEs are more likely to transition to a non-viable state than large firms. Further examination using the Cox model and the random effects model shows that SME dynamics are shaped by heterogeneous firm and industry characteristics, as well as the underlying financial and institutional environments. SME viability is distinguished by its ability to grow through learning along with age, aided by lower business risk, more focused business, access to equity finance, and less exposure to competition in remote regions. SME growth is constrained by a dispersed ownership structure, insufficient infrastructure to protect firms that are active in $R \& D$, and the limited financing role of equity markets. The study also reveals that government initiatives in support of strategic development in the service industries and in the coastal regions are of importance in spurring SME growth.
\end{abstract}

Key Words: SMEs; Industrial Organization; Capital Market; Institutions; China.

JEL Classification: L20; G32; P31; O53.

Jia Liu, Business School, The University of Salford, Greater Manchester, M5 4WT, United Kingdom, email: j.liu@salford.ac.uk. T +44(0)1612952981. 


\section{The dynamics of listed SMEs in China}

\section{Introduction}

Small and medium-sized enterprises (SMEs) have formed the backbone of every economy and served as the key source of economic dynamism and flexibility both in advanced industrialized economies and in emerging and developing ones (Oliveira and Fortunato, 2006). However, many SMEs do not survive their initial years in business due to their competitive disadvantages (Altman, 1983) and, as such, cannot provide full benefits to society. If they survive, they tend to deliver superior growth compared to their large counterparts (Jovanovic, 1982).

The dynamics of SMEs have been examined widely. The majority of the studies have been conducted based on the hypotheses formulated and explored for firms in mature economies and they have reached the consensus that firm attributes, industry characteristics, and external conditions are of fundamental importance in explaining SME survival and their long-term growth. A growing literature that seeks to understand the SME sector in emerging economies examines wider issues concerning firm dynamics by looking at the idiosyncratic economic system (Liedholm and Mead, 1999), politics and government policies (Rasiah, 2002; Nugent and Yhee, 2002) and institutions and infrastructure (Beck et al., 2002). It concludes that a marked difference exists in SME dynamics of mature versus emerging economies. However, none of the studies have yet analyzed SMEs in China.

Since China embarked on a comprehensive and ambitious economic reform in 1979, the SME sector has achieved remarkable growth and helped attain many important socioeconomic objectives. To help SMEs thrive, the Chinese government has initiated a series of supporting programs and set up a national network of agencies and institutions, with the objective of creating an enabling environment for the SME sector. The priority given to the SME sector is highlighted further in the Small and Medium-sized Enterprise Promotion Law promulgated in 2003, which specified that government bodies shall establish a system of services to legally protect SMEs' financial interests, in order to underpin the sustainable growth of the SME sector.

Despite the set of instruments, institutions, and regulations in place, it is widely believed 
that the development of SMEs has been hampered by institutional obstacles in the financial and business environment in which they operate. China practises the bank-based system, where the four national commercial banks dominate. Unlike their counterparts in mature economies, the Chinese commercial banks are controlled by the central and local governments and directed to channel financial resources to favored borrowers that are stateowned enterprises (SOEs) and strategic industries. They lack operational autonomy in making lending decisions on commercial terms. Bank monitoring and screening are, thus, seriously undermined. Developing sound and effective corporate governance was not put on the agenda until 2006 when the China Banking Regulatory Commission prescribed to the banking sector requirements for effective corporate governance. In the meantime, decentralization of administrative controls and institutional restructuring were initiated. These structural changes and the development of other financial institutions have induced the banks to make more viable financing decisions, helped them to channel financial resources to a broader range of sectors, including the SME sector, and boosted incentives for financial innovation (Liu and Pang, 2009). However, the continued dominance of the state, the restricted permissible scope of banking, as well as weak regulation and governance of bank institutions remain constant challenges to the continuance and sustainable growth of the SME sector.

The stock markets were not established until the end of 1991, initially for saving soon-tobe bankrupt SOEs. Qualified SMEs have since been allowed to file for listing on the Main Boards to tap new finance sources. However, strict criteria for market entry have excluded or discouraged the majority of qualified SMEs from equity financing. One of the important steps forward is that the Shenzhen Stock Exchange formally inaugurated a special board for SMEs in May 2004. The SME Board is open to SMEs that have an outstanding main business or are innovative high-tech start-ups, to facilitate the financing of those growing SMEs that badly need funds, but have few fund-raising channels. According to Yang (2005), the average lifespan of SMEs in China is 2.9 years. Publicly listed SMEs are required to show a minimum three-year profit record to qualify for market entry. This indicates that listed SMEs are the pioneers of the Chinese SME sector. Hereby, these questions arise: does being listed provide an unambiguous advantage for SMEs to attain sustainability in the 
market, and does the current business environment and institutional setting facilitate their post-market development after going public?

Although previous empirical studies provide valuable insights into SME dynamics, they are limited to the firm's post-entry performance after its inception; little is known about its post-market viability and growth and its major constraints after going public. In this study, we fill the void. We examine the explicit role of seasoned financing along with the roles of a range of explanatory variables relating to heterogeneous firm and industry specifics and institutional conditions in the post-market viability and growth of listed SMEs; and seek to better understand to what extent market and structural impediments constrain SME dynamics after they go public. The dynamics in the study are examined in two dimensions: 1) the firm's likelihood of transition to a non-viable state after market listing, and 2) the firm's after-market growth. The choice of publicly listed firms not only allows us to examine the importance of the antecedents mostly discussed in the literature, but also provides us with a unique opportunity to assess the financing role of the stock market in SME dynamics - which is neglected in the literature - as well as the extent of post-market business risk and agency problems associated with the public ownership structure of listed SMEs.

This study enriches the literature on firm dynamics by going beyond the traditional sizeage versus survival-growth relationship to demonstrate that access to capital market and seasoned financing mechanism, exposures to post-market business risk and agency problems associated with dispersed public shareholdings, institutional infrastructure and functions, as well as the government's supportive policies are of vital importance for the development of SMEs in an emerging economy where market reforms are only beginning to take hold. While the majority of previous studies concern manufacturing, this is one of the very few to study all industries and, hence, adds new empirical findings for an emerging economy. We are among the first to establish the direct link of cash flow effect and agency effect relating to business risk with the firm's viability and growth after it goes public. The paper's findings carry policy implications that are related to development of the stock market to meet SMEs' demands, improvement of corporate governance mechanisms, enforcement of intellectual property protections, and design and implementation of economic policies in support of industrial structure adjustments and creation of the favorable locational conditions in the less- 
developed regions.

\section{Empirical Evidence on Firm Dynamics}

Firm dynamics have been studied in various disciplines. There has been theoretical support and empirical evidence that firm dynamics are determined by the characteristics specific to the firm and the industry and the external conditions that are critical to the firm's continence and growth.

Theoretical models have developed to show that the underlying firm specifics shape the firm dynamics. Jovanovic (1982) models firm survival and growth as a function of the efficiency level of a firm. The start-up firm enters the market unsure of its true quality and learns about its efficiency through market information on its performance over time. The firm that gains the ability to compete through learning will survive along with its size and age. If the new firm is able to occupy a niche in the market, it will grow faster than the incumbent firms. Jovanovic's work has challenged the random growth hypothesis, also known as Gibrat's Law, which asserts that growth is unrelated to firm size. Supporting evidence for the Jovanovic hypothesis has been found in a rich array of empirical studies on firm dynamics, e.g., Evans (1987) on the relationships of firm survival with firm size and age and Audretsch et al. (1999) on the interactive effect of size-age on firm growth.

Economic research has paid considerable attention to business risk when assessing firm dynamics (Bowman, 1980). The Capital Asset Pricing theory proposes that if market efficiency exists, business risk has no effect on firm value, as the risk can be diversified away by investors. Opponents argue that business risk is central to organizational evolution (Child, 1972). Uncertainty in investment and operational outcomes can largely increase the variability in the firm's future cash flows and hence reduce its ability to meet fixed charges (Bernanke, 1983), leading to a higher probability of default and thereby damaging the firm's chance to grow (Brito and Mello, 1995). The negative earnings shocks can have an adverse effect on the firm's reputation and its business relations with customers, and hamper its ability to pursue profitable growth options and realize the full value of its assets (Stulz, 1996). However, lower business risk can be negatively linked with firm value. Instead of maximizing firm growth, management may seek to maintain a lower level of business risk by 
opting to under-invest, leading to deterioration in firm value (Amit and Wernerfelt, 1990).

The association of firm dynamics with ownership structure has been the subject of an important and ongoing debate in the literature. The separation of ownership and control creates conflicts of interest between management and shareholders, which has negative implications for firm performance and valuation (Jensen and Meckling, 1976). Especially when ownership is overly dispersed, monitoring can be ineffective and passive (Grossman and Hart, 1988), because small, rationally apathetic shareholders have no adequate incentives to monitor management closely (Berle and Means, 1932). However, if the investors, such as institutional ones, have an adequate incentive to monitor management closely and the ability to direct strategic change because of their voting blocks (La Porta et al., 1999), agency problems are likely to reduce and firm value is, thus, enhanced. In contrast, Fama (1980) proposes that ownership is irrelevant to firm dynamics when the market for control is in place and can effectively discipline management discretional behavior and solve incentive problems.

Industrial literature has provided compelling evidence that industry-specific characteristics concerning economies of scale and industry-level innovative activities play important roles in determining firm dynamics (Bartoloni and Baussola, 2009). The survival rate of new entrants is subject to the degree of economies of scale in the industry where they operate. A higher level of the minimum efficient scale level of output required by the industry indicates cost disadvantages for the new entrants and lowers their chance of surviving in the short run (Acs and Audretsch, 1990) as well as in the long run (Audretsch, 1991). Nevertheless, the likelihood of survival depends on how rapidly the new entrants grow towards the minimum efficient scale level (Audretsch and Mahmood, 1995). Once the new entrants are able to survive in the capital-intensive industries, they have a greater propensity to grow (Doms et al., 1995). Theoretical models have developed to consider the technological environment and regime that can have long-run implications for the ability of new value-maximizing firms to innovate and therefore survive (Gort and Klepper, 1982). New firms tend to survive in the industries with innovation advantages (Agarwal and Audretsch, 2001). The entry accompanied by the breakthrough in knowledge provides the new firms with comparative advantages to survive over the incumbents with obsolescent 
knowledge (Agarwal and Gort, 1996); however, survival varies with technology evolving along the industry life cycles (Agarwal and Audretsch, 2001).

There is substantial research on the importance of external conditions in determining firm dynamics. Many studies focus on the role of external finance and conclude that firm survival and growth potential can be seriously constrained by the scarce availability of external finance (Zingales, 1998). In the presence of asymmetric information, firm investment is unequally financially constrained and liquidity constraints become more severe as firm size decreases (Fazzari et al., 1988). Due to the limited access to equity finance, small firms have to rely more heavily on bank loans than their larger counterparts. In the face of severe adverse selection problems, small firms are excluded from the market, which results in valuable investment opportunities being missed (Stiglitz and Weiss, 1981), thereby limiting their ability to grow. The financial market environment is part and parcel of firm dynamics too, out of which stock exchange regulations governing the issuance and trading of securities as well as operational and informational efficiencies of capital markets are claimed to be the most important factors in determining firm growth (González, 2002). Small firms, where information asymmetry is substantial, often have difficulty in establishing and maintaining liquid and efficient markets for their securities, which adversely affects their growth prospects (Enisan and Olufisayo, 2009).

A growing literature has developed which examines the ways in which firm dynamics are related to location attributes. The economic characteristics of regional markets and infrastructure, i.e., proximity to suppliers and customers, research, administrative mechanisms, and transport infrastructure, play important roles in firm dynamics (Eickelpasch et al., 2007). Regional institutional and cultural factors that attract talent and human capital contribute to technological development and productivity in the region, which, in turn, influence the survival and growth of new entries (Werner, 2004). Superior access to knowledge resources offers the synergy to firm growth too. A location rich in knowledge resources is more conducive to firm growth than the one that is less endowed (Audretsch and Dohse, 2007). In contrast, firm dynamics can be disadvantaged by an unfavorable locational environment. Inefficient administrative arrangements and market barriers, even in regions where market and opportunities are expanding, would hamper firm growth (Czarnitzki and 
Hottenrott, 2009). Fierce competition can lead to the higher likelihood of firm exit too (Hansen et al., 2004).

A body of literature has emerged recently that examines the extent to which the institutional environment and infrastructure influence firm dynamics. Some country studies show that SME dynamics are closely linked with, among others, market conditions and the institutional framework of the individual financial system (González, 2002), as well as financing environment and legal institutions with the most fundamental aspects pertaining to protection of property rights and enforcement of legal contracts (Beck et al., 2002). In summary, the differences in economic, political, and institutional contexts have played significant roles in explaining the differentials in SME dynamics across economic systems.

In what follows, we rely on the above framework to examine the dynamics of listed SMEs in China and discuss the extent to which Chinese listed SMEs fit into the general pattern.

\section{Methodological Issues}

\subsection{Survival Analysis Methods}

The stock market in China did not have an exit mechanism until 1998 when the securities regulator, the China Securities Regulatory Commission (CSRC), promulgated the trading suspension and delisting rules. The general principle is that if a firm experiences negative net profits for two consecutive accounting years, it will receive a delisting risk alert from the CSRC. The stock exchange will put its shares under special treatment, and the daily up and down limit of its share price will be reduced to 5 percent. If its net profit remains negative for a third year, the firm's shares will be suspended from trading on the Main Board and the firm will be delisted from the stock market after the approval of the CSRC. In this study, if a firm experiences negative net profits for two consecutive years, it is considered to be in a nonviable state in the market; otherwise, it remains viable in the market. The rationale of the two-year cutoff is that a two-year loss signifies the start of the operational abnormality of a listed firm and is the first sign of danger of progression to trading suspension and being delisted from the market. We employ statistical methods for survival data analysis, the recurrent Kaplan-Meier Procedure (Kaplan and Meier, 1958; Peña et al., 2001) and the Cox model with counting process (Cox, 1972; Andersen and Gill, 1982), to estimate the firm's propensity to transition to a non-viable state and identify the factors that determine the 
transition of SMEs in comparison to large firms (control group). The survival analysis methods allow us to track the effects of potential factors on the firm's post-market viability over its entire time profile after going public.

\section{Kaplan-Meier Estimation Method}

The Kaplan-Meier (KM) estimation method provides a descriptive view of a firm's propensity of transitioning to a non-viable state by modeling time-to-event data. The KM method takes into account the time to the first hazard event, and counts the firms at risk at the time of the event. The event in this study is defined as a firm being loss-making in net profit for two consecutive years, and the risk set is defined as a collection of the firms that are at risk of making such a loss at a certain point in time since listing on the stock market. The recurrent KM procedure generates step-function estimates of survival for each point in time at which an event occurs or recurs. Let $0<t_{1}<\cdots<t_{r}<\infty$ be the observed, ordered failure times. The estimator, $\hat{S}(t)$, is expressed as

$$
\hat{S}(t)=\prod_{j \mid t_{j}<t}\left(1-\frac{E_{j}^{*}}{R_{j}^{*}}\right)
$$

where $E_{j}^{*}$ represents the number of event occurrences or recurrences at time $t_{j}$, and $R_{j}^{*}$ represents the number of firms at risk at time $t_{j}, j=1, \ldots, r$. Equation 1 estimates the firm's likelihood of transitioning to a non-viable state based on the individual firm's information at time $t_{j}$ and prior periods by calculating the probability of an occurring or recurrent event. Each firm enters the risk in the year when it is listed on the stock market, and ends when it is delisted from the stock market or at the end of 2008, when the survival time is censored. If an event occurs, all the recurrences during the follow-up period are taken into account.

The estimation results are displayed as recurrent Kaplan-Meier curves, where the survival rates are plotted against the years since listing. The Breslow test of homogeneity is then applied to test whether the survival pair distributions of SMEs and large firms are equal.

\section{Cox Proportional Hazard Regression Model}

The Kaplan-Meier estimation, while informative, does not enable us to examine the factors that may account for the heterogeneous propensity of transitioning to a non-viable state of the 
firms of different sizes.

The Cox proportional hazard regression model is a multivariate survival method widely used in failure time studies. The baseline hazard function assumes one time event per firm. Andersen and Gill (1982) extend the Cox model to take account of multiple events, henceforth the Cox model with counting process. The counting process allows firms to experience multiple events by entering and leaving the risk set at any number of points in time, while keeping them on the same baseline hazards. The formulation of the counting process proposed by Andersen and Gill (1982) can be written as

$\lambda_{i}(t)=\lambda_{0}(t) e^{\beta^{\prime} X_{i}(t)} Y_{i}(t), \quad i=1, \ldots, n$

where $\lambda_{t}\{(t),(X)\}$ denotes the resultant hazard of firm $i$ with the time interval $[0, t]$, given the values of the covariates for the respective case in $X ; Y_{i}(t)=\left(Y_{i, 1}, \ldots, Y_{i, n}\right)$ is the multivariate indicator process, referred to as the censoring process, with $Y_{i}(t)=1$ if the $i$ th firm has an occurrence or recurrence of loss-making at time $t$ since the year of listing or $Y_{i}(t)=0$ otherwise; and the term $\lambda_{0}(t)$ is the baseline hazard for the respective firm when all explanatory variable values are equal to zero. Hazard ratio $(H R)$ per unit increase in $X_{i}(t)$ is estimated as $e^{\beta^{\prime}}$, and $\beta$ is the regression coefficient. In this repeated event context, the observations are assumed to be independent of each other for a given firm. However, it is likely that the chance of the firm experiencing loss-making is dependent on any earlier losses that have occurred. Hence, the standard errors will be adjusted for robustness to account for the dependence of observations within the firm over time. A negative coefficient on the $H R$, $H R<1$, indicates that the explanatory variable is associated with the higher probability of viability in the firm. A positive coefficient, $H R>1$, suggests that the explanatory variable accelerates the occurrence or recurrence of loss-making in the firm and hence it has a greater likelihood of transitioning to a non-viable state. When the estimated $H R$ is unity, the explanatory variable has no influence on the viability of the firm.

\subsection{Panel Data Analysis of Firm Growth}

This study applies the panel data analysis technique to examine post-market growth of SMEs. The general econometric model is specified below. 
Growth $_{i, t}=\beta_{0}+$ Growth $_{i, t-1}+X_{i, t} \beta+\alpha_{i}+\alpha_{t}+\varepsilon_{i, t}$

where Growth ${ }_{i, t}$ is the growth rate for firm $i$ at time $t ; X$ is a vector of antecedents; $\alpha_{t}$ and $\alpha_{i}$ represent time effect and unobserved heterogeneity of the ith firm respectively; and $\varepsilon_{t}$ is a white noise error term. To examine the dynamic property of this equation, we add the lagged dependent variable, Growth $_{i, t-1}$, to control for the endogenous determination of firm growth (Caselli et al., 1996). $\alpha_{i}$ can be treated as a fixed parameter over time, in which case the $i$ th intercept is $\beta_{0}+a_{i}$ as in the fixed effects estimation. We can also treat $\alpha_{i}$ as a random parameter, with the assumption that the intercept is a random outcome variable that is a function of a mean value plus a random error. Hence, a composite error term is formed as $v_{i, t}=\alpha_{i}+\varepsilon_{i, t}$. Because $\alpha_{i}$ is in the composite error in each time period $t$, the error term, $v_{i, t}$, can be serially correlated with any of the explanatory variables across the periods in the estimation. The Hausman specification test is used for orthogonality that the individual effects are uncorrelated with the regressors in the model, that is, $E\left(\alpha_{i} \mid X_{i, t}\right)=0$, assuming other model assumptions are met (Hausman, 1978). If $H_{0}$ is rejected, the fixed effects model is estimated. If $H_{0}$ is accepted, the random effects model is favored over the fixed effects model as it has a more efficient estimator and is statistically justifiable to be estimated.

\subsection{Data}

In examining the dynamics of listed SMEs, we employ the full history of annual panel data of the firms listed on the Shanghai Stock Exchange and the Shenzhen Stock Exchange in the period 1991-2008. ${ }^{1}$ The firms are of different sizes and are distributed across 12 types of industry excluding banking and insurance. All the firms, including suspended and delisted ones, are included. The final sample for this analysis comprises 1,582 firms. The expected relationship of firm dynamics with a set of variables relating to firm attributes, industry specifics, and external conditions and the theory behind each characteristic are discussed below. The definitions are summarized in Table 1 .

1. We employed the Seasoned Equity Offerings Database, China’s Bond Market Database, China's Stock Market Database, and the Accounting Research Database developed by the Centre for China Financial Research of the University of Hong Kong and Guo Tai An Information Technology Company. The Sinofin Database, developed by Beijing University, supplied the ownership database. The National Bureau of Statistics of China supplied the annual industry-specific GDP growth index. 
Insert Table 1 here.

The first group of variables are the key variables specific to the firm. Firm size is closely correlated with firm dynamics. Small firms have limited resource in terms of finance, technology, and personnel but higher risk in operations, and hence are less able to achieve economies of scale rendering them competitive in the market (Aaby and Slater, 1989). In the extreme case, they are forced out of the market. Once small firms secure a niche in their respective markets, they tend to grow faster than their large counterparts (Jovanovic, 1982). We would, therefore, expect that size is positively related to firm viability but negatively related to firm growth. Start-up size is used to enable us to link firm dynamics to its ability to attract financial resources (Persson, 2004) and to the cost disadvantage of confronting the small start-ups that typically operate at a sub-optimal scale of output (Evans, 1987), which, in turn, determine its ability to survive and grow. To test the size effect, we classify the firms in accordance with the size classification jointly issued by the State Economic and Trade Commission, the State Planning Commission, the Ministry of Finance, and the National Bureau of Statistics. A firm is classified as an SME if it meets one of these two criteria: 1) the firm is officially listed on the SME Board of the Shenzhen Stock Exchange; 2) the total number of shares outstanding is less than $200,000,000$ and the total number of tradable shares outstanding is less than 50,000,000; otherwise it is a large firm. This classification is also adopted by the SME Board. Firm size is defined as being equal to 1 if a firm is small and medium-sized, or 0 if it is large. Large firm size is used as the reference size.

Firms evolve with age. Young firms have a high mortality rate, but the rate declines as they age and turn competitive (Jovanovic, 1982). Chinese listed firms, small or large, are generally young. The history of listed firms can only be traced back to the experiment with corporatization, which began in 1984 . To be listed on the stock market, the enterprises are required to restructure themselves into shareholding companies before being considered for listing by the CSRC. In December 1990, the two stock exchanges started off tentatively with medium-sized SOEs mainly operating in the traditional industries. An increasing number of firms were incorporated and went public from 1998. These new incorporations tended to be large-scale firms or blue chips operating in the strategic industries or holding the leading 
position in their respective industries. With the set-up of the SME Board in 2004, SMEs with high growth prospects and leadership in their own line of business were also incorporated and 38 of them were approved for listing on the SME Board. This number increased to 277 at the end of 2008. In view of the specific age spectrum of listed firms, we expect younger incorporated firms to have better growth prospects than their relatively older counterparts, especially in SMEs, in that if an SME is incorporated and qualified for listing, it demonstrates that it has gained strength through learning (Jovanovic, 1982) to attract financial resources, which, in turn, signifies its strong capacity to grow. However, it is also likely that the age effect is indistinguishable, as listed firms in China are, in general, young. Age is defined as the attained age representing the lifetime of a firm in each calendar year.

The firm's post-market growth represents its capacity to sustain the underlying operations and growth potential after going public. A smaller firm with a higher growth rate would have a better chance of surviving, as “The superior endowments of a firm, reflected in its ability to grow, increase the probability of survival” (Agarwal, 1997). We define the post-market growth rate as the annual growth rate in total assets of firm $i$ in year $t$ after going public and expect a positive effect of this variable on firm viability. As this study covers 18 years from 1991 to 2008, the firm's investment and operating activities may have been affected by the ups and downs in the economy. To account for the possible effect of economic fluctuations, the variable is derived after adjusting the calendar-year and industry-specific GDP growth index. This variable is also used as the independent variable in the post-market growth analysis.

Business risk can determine which organizations survive and grow and which decline and die (Summer, 1980). An increasing level of business risk can largely increase uncertainty in the firm's projections of future incomes and hence reduce its ability to meet debt obligations (Bernanke, 1983), leading to a higher probability of not surviving. So we refer to this effect as the cash flow effect. On the other hand, a lower level of business risk may be the consequence of managerial deliberation to maintain a stable earnings stream through incurring agency costs, thereby damaging firm growth. We refer to this effect as the agency effect. We measure business risk as the standard deviation of the residual term $\varepsilon_{i, t}$ in the 
market model, which is expressed by

$R_{i, t}=\alpha_{i, t}+\beta_{i, t} R_{m, t}+\varepsilon_{i, t}$

where $R_{i, t}$ is the individual return of security with cash dividend reinvested of firm $i$ in year $t$, and $R_{m, t}$ is the equally weighted market return with cash dividend reinvested in year $t$. We posit that business risk is negatively related to firm viability. Higher business risk increases the likelihood of the firm's transition to a non-viable state, given uncertainty in generating returns. Business risk is positively linked with firm growth, given the risk-return relationship. If management choose to under-invest in order to reduce business risk, firm growth decreases as a consequence.

A unique feature of Chinese listed firms is the dual ownership structure represented by tradable shares, i.e., public shares, and non-tradable shares, including state shares and legalperson shares. Although different classes of shares have the same claim rights and voting power, their holders differ in the motivation of monitoring managerial behavior in alignment with shareholders' interests. Listed SMEs are predominated by public shareholdings. The vast majority of public investors are minority shareholders holding a negligible amount of shares. They lack adequate incentives to monitor management closely, and public shareholder passivity is, thus, inevitable. Additionally, almost no individual shareholders sit on the board of directors or on the supervisory committee (Xu and Wang, 1999). They would face significant hurdles when seeking to assert their rights within the corporate system. Furthermore, there is no sufficient market infrastructure for legal protection of shareholders' rights due to unclearly defined property rights. We hypothesize that the overly dispersed public ownership structure in SMEs would discourage the shareholders from restraining managers’ prerogative discretions and dealing with misconduct of dominant shareholders and, hence, have negative implications for SME dynamics.

Non-state legal-person ownership holds second position in the SMEs' ownership structure. Different from public shareholdings, there is a broader range of monitoring devices under non-state legal-person shareholdings. Non-state legal-person shareholders, who are institutional investors, elect the representatives to the board of directors and the supervisory committee to protect their interests (Sun and Tong, 2003). They also specialize in gathering 
and interpreting sophisticated information on firms (Grier and Zychowicz, 1994). Hence, they have more incentive and capability to monitor the implementation of corporate strategies, change the management team, and discipline incumbent management in the wake of performance decline or in the presence of managerial entrenchment. Our corresponding hypothesis is that institutional shareholdings are positively associated with SME dynamics.

State ownership is derived from the legacy of the centrally commended economy and is intrinsically ambiguous (Driffield and Du, 2007). In principle, state shares are owned by every Chinese citizen. In reality, government bureaucrats represent their interests and act as the principal, but they are not legally entitled to residual incomes. Bureaucrats select top managers, who are politically or personally linked with them, and delegate the control rights over operations, assets, and cash flows to management. Under such corporate governance arrangements that do not serve the purpose of safeguarding firm value, managerial incentives are skewed to maximize personal benefits or pursue political goals, leading to substantial agency problems (Shleifer, 1998). As state shares account for the least ownership of SMEs (see Table 3), we posit that the likely negative effect should be modest or insignificant on SME survival and growth but large and significant for large firms that are dominated by state ownership. The three classes of ownership are measured as the percentage of total shares outstanding within a firm. They consist of tradable A-shares, non-state legal-person shares, and state shares, respectively. State ownership consists of state shares and state legal-person shares.

The second group of determinants relates to industry specifics. The type of business in which a firm operates determines the firm dynamics (Audretsch and Mahmood, 1995). The common observation is that the more capital intensive the industry in which a small firm operates, the less chance it has of surviving. If the small firm is able to survive, it will have experienced extraordinary growth (Audretsch, 1995). The real sector in China was long characterized by the government's industry policies targeting strategic industries in the prereform period. Since the 1980s, the government has aspired to promote a multi-tiered industrial structure with the objective of improving the competitiveness of Chinese industries, and the industry policies have been gradually geared towards supporting the tertiary industries in which SMEs actively operate. Furthermore, the industry-level technological 
activities and the innovative environment influence the general conditions for firm survival (Agarwal and Audretsch, 2001). The firm-specific strengths of dealing with external changes are consolidated during the process of R\&D and innovative activities (Christensen and Caves, 1997). The Chinese government attaches great importance to the development of SMEs and provides policy support to encourage SMEs to engage in R\&D and technological innovation. SME innovation has been taking place, and innovative SMEs are playing a pivotal role in leading the development of the SME sector. However, the role of R\&D and innovative activities can be undermined by the prevalence of copyright infringement and weak institutional protections of innovative and R\&D-active firms. Trademark counterfeiting and piracy are the most common intellectual property rights violations in China. Innovative and R\&D firms often find their new products copied very quickly. The laxness of copyright enforcement by local authorities has exacerbated the piracy problems, allowing staggeringly high piracy rates and massive losses for these firms.

To test the industry-specific effect, we classify the firms into 12 industries in accordance with the four-digit CSRC Guidelines on Business Classification promulgated in May 2001. Of these industries, the innovative high-tech and $R \& D$ sector include firms within section $G$ (Information Technology), firms in the innovative high-tech sub-sectors of Manufacturing within division C5 (Electronics) and division C8 (Medicine and Biological Products), and firms in Social Services within division K20 (Professional, Scientific Research Services). We assign 12 industry dummy variables to represent each of the industries (see Table 1 for details). Agriculture is used as the reference industry. On average, agricultural establishments are labour-intensive with less capital commitment, and one can assume that there are fewer economies of scale in the industry. We hypothesize that SMEs in the service industries are more likely to survive and those in the capital-intensive industries are more likely to grow. We also expect that the governmental policies and supports that have vigorously promoted productivity and independent technological innovation of SMEs in the last two decades have effectively contributed to SME dynamics. Given the extent of copyright infringement and the resulting impairment on the market value of $R \& D$ and innovation outputs, it is likely that industry-level innovative high-tech and R\&D activities have less effect on SME growth than would otherwise be expected. 
The third group of determinants includes variables describing the external environment that may influence firm dynamics. SMEs need capital in order to finance their growth and expansion, and a lack of financial resources is a major impediment to their development (Carpenter and Petersen, 2002). To help ease SME finance, qualified SMEs have been allowed to float on the Main Boards of the two stock exchanges since 1991. In 2004, the Shenzhen Stock Exchange officially inaugurated the SME Board targeting the emerging SMEs with outstanding main business or innovative advantages. However, the seasoned issue requirements that apply to large firms unanimously apply to SMEs too ${ }^{2}$. Many SMEs find it difficult to meet such criteria at the early stages of their development. According to our data set, 53 percent of large firms meet the criteria, while only 16 percent of SMEs qualify. In addition, the issue procedure is lengthy and costly, and can take up to two to three years to complete. Furthermore, the convertible bond market is virtually non-existent for SMEs, as convertible bond issues are only targeted at large firms ${ }^{3}$. Given these constraints, we postulate that the role of seasoned financing in firm dynamics is limited and the capital market may have failed to fulfill the financing role that it would normally be thought to assume in providing much-needed finance to listed SMEs. The variable representing seasoned financing, expressed as the ratio of gross proceeds raised through rights issues, cash offers, and convertible bonds conducted by firm $i$ in year $t$ over its market capitalization at the accounting year end preceding the issue, is included to test whether equity finance is of significance in firm dynamics, shedding light on the financing role of the equity market in sustaining firm growth.

The economic value of location serves as a conduit for higher rates of firm growth

2. According to the Provisional Regulation on Rights Issues by Listed Companies promulgated in 1993 and revised in 1994, 1996 and 1999 and the Measures for the Administration of Offerings of New Shares by Listed Companies promulgated in 2001 and revised in 2006, SMEs must meet the following criteria to be eligible for rights issues or cash offers: 1) the company must have been continuously profitable for the last three accounting years; 2) the weighted averaged ROE should be no less than 10 percent in the last three accounting years and no less than 6 percent in the year preceding the intended issue; 3 ) the shares in the previous issue must have been fully subscribed and there must have been at least a 12-month interval between any two issues.

3. Based on the Interim Measures for the Administration of Issuance of Convertible Bonds by Listed Companies promulgated in 1997 and revised in 2001 and 2006, a firm needs to meet the following requirements to qualify for the convertible issue: 1) the minimum issue amount should not be less than 100 million yuan; 2) net assets should not be less than 2.5 billion yuan; 3 ) the company must have been continuously profitable and the weighted averaged ROE should not be less than 10 percent in the last three accounting years. 
(Audretsch and Dohse, 2007). In 1979, China embarked on overall economic reform, opening up to the outside world. Since the 1980s, the Chinese government has established four Special Economic Zones and further opened up some coastal cities and regions. The government grants these cities and regions preferential policies, such as special tax incentives for foreign investment, greater autonomy when conducting international trade activities, greater fiscal autonomy, and favorable terms on loans and subsidies, with the objective of creating a favorable environment to attract foreign investment and promote infrastructure development, thereby stimulating market-oriented economic growth. Greatly aided by local economic booms, these cities and regions have gradually developed into the national center for science and technology as well as commerce and finance, the hub of talents and knowledge, and the modern industrial base. Given the policies aiming at enriching certain cities and regions, we would not expect the regional economy to experience the same level of enhancement in terms of productivity and growth, but instead expect the cities and regions that benefit the most from the policies to have a higher growth rate. To test the effect of location on firm dynamics, we group firms, based on their openness to the outside world, into the coastal region, the inner region, and the remote region. We use dummy variables to represent the three regions in the estimation. The remote region is used as the reference region. This region is characterized by heavy usage of traditional production, less developed technologies, and lack of social and human factors, compared to the other two regions (see Table 1 for details).

Table 2 presents size distributions by industry sectors and locations summarizing the idiosyncratic characteristics of Chinese listed SMEs. It is evident that more than half of the listed SMEs operate in Manufacturing, partly because China has become the largest manufacturing country in the world and the development of the SME sector is promoted by buoyant exports, and partly because Manufacturing holds the dominant position in Chinese industry. It is also noted that a significant percentage of large firms operate in Manufacturing (45\%). Nevertheless, listed SMEs are active in the services industries (37\%). It appears that more SMEs (23\%) than large firms (15\%) engage in innovative high-tech and R\&D activities. In terms of size distribution by location, the majority of SMEs are located in the coastal region while those in the remote region account for the least, and large firms have a similar pattern. The general picture reveals that listed SMEs tend to be active in innovative high-tech 
and R\&D activities, operate in Manufacturing and the service industries, and congregate in the open, coastal region.

Insert Table 2 here.

Table 3 presents medians and standard deviations of the key variables used in the econometric analyses. SMEs tend to be younger (7) and have a higher growth rate (3.23) and also higher business risk (0.84) compared to large firms. Not surprisingly, state ownership increases with firm size from 24.5 percent in SMEs to 34.6 percent in large firms. This is consistent with the fact that most large listed firms were originally SOEs. The percentage of shares held by non-state legal-person shareholders has an opposite trend, decreasing from 26.7 percent in SMEs to 18.2 percent in large firms. Similarly, the percentage of tradable Ashares decreases from 40.1 percent in SMEs to 32.6 percent in large firms. The ownership structure indicates that public shareholdings are a dominant feature of Chinese listed SMEs. Furthermore, the seasoned issues to market capitalization ratio is two times lower in SMEs (0.023) than in large firms (0.049), providing evidence that SMEs have raised far fewer seasoned funds to finance their corporate activities.

Insert Table 3 here.

\section{Empirical Findings}

\subsection{Firm's Post-market Viability}

Figure 1 illustrates the viability rates of SMEs in comparison to large firms after their inception into the stock market. For the first two years, the estimated viability rates of SMEs maintain a similar level to those of large firms. From the third year onwards, the rates are below those of large firms throughout the period, and the difference increases as the viability rates of the two groups follow divergent paths over time. By the end of the fifth year, the viability rate of SMEs falls to 33 percent, while that of large firms is maintained at the 75 percent level, indicating that 67 percent of SMEs incur losses in their first five years after market entry, while only 25 percent of large firms have such a problem. After ten years, the viability rate drops to 8 percent in SMEs and 50 percent in large firms, before plateauing. The overall results indicate that SMEs are more likely to incur losses than large firms, and their losses accumulate at an accelerating pace over the period. The Breslow log-rank test for 
equality of survivor functions shows that $\chi_{1}^{2}=159.03(\mathrm{P}<0.01)$. Therefore, the result does not support that the survival functions of SMEs and large firms are identical.

Insert Figure 1 here.

The disparity in the viability of the two groups suggests that certain underlying factors have accounted for the heterogeneous probabilities of hazard confronting firms of different sizes. We will undertake the Cox regression to analyze the factors that may have underpinned the above findings.

\section{Insert Table 4 here.}

Table 4 presents the results of analyzing survival-time data by the Cox regression for SMEs, large firms, and all firms. For the full sample, the hazard ratio on firm size $(H R=1.44)$ is highly significant at the 5 percent level, providing evidence that SMEs face a significantly higher risk of transitioning to a non-viable state than their large counterparts. We also regressed on the continuous size variable defined as the logarithm of turnover and the logarithm of total assets of firm $i$ in year $t$, respectively (not reported to reserve space). The results consistently show that firm size is negatively related to the likelihood of hazard occurring. Collectively, the regressions and the graphical analysis on the size effect are in agreement with most of the theoretical and empirical literature on firm dynamics. Given the significance of size in determining the firm's post-market outcomes, we will conduct separate analyses for SMEs and large firms (control group) hereinafter, to explore the ways in which heterogeneous firm and industry characteristics and external conditions determining the firm's post-market transition states vary with firm size. Firm viability is positively associated with firm age $(H R=0.86)$, indicating that there is advantage bestowed as the firm gets older. Post-market growth protects firms from evolving to a non-viable state, which echoes the popular view that firms that do not grow or expand ultimately fail. There is a negative relationship between business risk and firm viability, which, thus, supports our hypothesis about the business risk-related cash flow effect. Firm viability decreases with state shares while increasing with non-state legal-person shares, but the relation between viability and A-shares has not been identified, although the hazard ratio is correctly signed. Industry-level innovative high-tech and R\&D activities lead to higher firm viability, but the 
impact is not overwhelming $(H R=0.84)$. Firms operating in the capital-intensive industries, Mining and Quarrying, Manufacturing and Utility, are more likely to remain viable than those in the service industries, showing that length of survival is a function of industry characteristics associated with capital intensity. However, this result may only reflect the position of large firms, given their dominance in the population of listed firms, pointing out the need to look at the differential impacts of industry specifics by firm size. It reveals that the funds raised through seasoned financing are of importance in sustaining firm viability $(H R=0.88)$. Further evidence shows that firms situated in the coastal region have a greater likelihood of transitioning to a non-viable state than those in the inner and remote regions.

The second and third columns in Table 4 present the effects of antecedents on the likelihood of the SME's transition to the viable versus non-viable state in comparison to large firms. The viability of SMEs is positively correlated with firm age $(H R=0.76)$, consistent with the view that learning-by-doing is an important determinant of firm survival (Jovanovic, 1982; Sutton, 1997). However, for large firms, there is not much difference between younger firms and more mature ones $(H R=0.94)$, due to the typical age structure of Chinese listed firms. Post-market growth has a significant, positive effect on SME viability, indicating that SMEs that have grown more rapidly have a better chance of remaining viable. This result lends support to the claim of Mata et al. (1995) that the rate at which smaller firms grow does matter in shaping their survival. However, the hazard ratio on large firms is not statistically significant. The insignificance indicates that large firms do not need to grow to survive. Rather, large firms, which are normally in the mature phase of the life cycle, can remain large and meanwhile avoid being confronted by a higher likelihood of hazard occurring by holding steady onto the niche market. When it comes to business risk, the cash flow effect prevails, showing that high business risk can threaten firm viability. The effect is more pronounced in SMEs $(H R=1.45)$, suggesting that the capacity of SMEs to sustain the stability of cash flow is far more important than that of large firms.

Firm viability is significantly negatively correlated with tradable A-shares, confirming that diffused public ownership does not contribute to the viability of Chinese firms. As expected, the effect is stronger in SMEs where public ownership predominates. Non-state legal-person shares have a significant, positive impact on SME viability $(H R=0.54)$ and, to a lesser degree, 
the effect is also found in large firms $(H R=0.66)$, demonstrating that an ownership structure composition with relative dominance of institutional shareholdings can effectively increase the firm's post-market viability. Consistent with our hypothesis, state ownership has not made an impact on SMEs. However, it shows a modest, protective effect on the large firm cohort $(H R=0.91)$. This result is not surprising. Large firms are ultimately controlled by the state and mainly operate in the strategic industries and shoulder social responsibilities in the national economy. If they run into cashflow or operational problems, the government would protect them by providing various financial support and/or changing senior management, as argued by Anderson et al. (2000) for the economies, like China, that lack market mechanisms and institutions. In the meantime, management would work collectively to save the firm from imminent trouble by improving operational efficiency.

Industry specifics show distinguished different effects on the firm's post-market viability. SMEs operating in the capital-intensive industries, such as Mining and Quarrying $(H R=1.27)$, Manufacturing $(H R=1.23)$, and Construction $(H R=1.12)$, have greater probabilities of transitioning to a non-viable state, but large firms do not experience such problems. The evidence supports the hypothesis of Jovanovic (1982) that it is more difficult for smaller firms to survive in the industries characterized by large units. On the contrary, SMEs find it much easier to remain viable in some of the service sectors, such as Wholesale and Retail Trade $(H R=0.61)$ and Social Services $(H R=0.69)$. These industries are less aggregated and less intensive in capital required to generate economies of scale, compared to those heavy industries. However, smaller establishments in Real Estate have a significantly higher hazard ratio ( $H R=1.22$ ), while the opposite holds for large firms. The real estate sector in China is increasingly volatile and the estate market is plagued with big bubbles. This highlights that listed SMEs find it particularly hard to remain viable in volatile industries. What is noteworthy is that both SMEs and large firms in the innovative high-tech and R\&D sector have greater post-market viability. This finding supports the views of Doms et al. (1995) and Agarwal and Audretsch (2001) that innovative conditions at the industry level do matter for the continuance of the firm. Their relative importance/more relevance to for SMEs highlights that the capability of Chinese SMEs to create and commercialize new knowledge is fundamental to their sustained competitiveness. Large firms in the Communication and 
Culture industries are more likely to remain viable, but no evidence is found for SMEs. Firms in Conglomerates are confronted with a higher risk of evolving to a non-viable state, in particular SMEs ( $H R=1.38)$, suggesting that stepping up and focusing on the core business is important in securing the position of business and driving sustainable competitive advantage as soon as the firm enters the market. This evidence has important implications for management when formulating and designing business strategies.

The study confirms our hypothesis that seasoned financing is an important determinant of SME viability after they go public, and it is noted that seasoned funds have a larger impact than any other variables in the regression $(H R=0.42)$, highlighting the importance of equity capital for SMEs in their continuance in the market. This leads us to believe that any disruptions in their financing activities can be detrimental to the sustainability of SMEs. But there is not much evidence that seasoned funds exert an influence on the viability of large firms, suggesting that large firms have other financing channels than the stock market, and hence do not rely upon equity capital to survive.

The study reveals the importance of location in firm viability. The hazard probability of SMEs in the coastal region is apparently higher $(H R=1.25)$ than that of those in more remote parts of China. SMEs in the coastal region operate in an open economic environment, facing pronounced competition and being exposed to strong market fluctuations, which poses a threat to their viability. In the inner region and particularly in the remote region, local governments are protective of existing firms and have established administrative and structural barriers to entry. SMEs in these regions are more oriented towards serving local markets, and therefore tend to escape some of the survival risks faced by those in the more outward-oriented regions. However, statistical insignificance on the hazard ratio for large firms indicates that location is not a determinant of large firm viability, providing further evidence that size is important in explaining SME dynamics in China.

\subsection{Firm's Post-market Growth}

Table 5 presents the results of the post-market growth analysis. We carried out Hausman tests to choose the model for estimation, and the results accepted the null hypothesis that the coefficients estimated by the efficient random effects estimator are the same as those 
estimated by the consistent fixed effects estimator $(\mathrm{p}>0.05)$ for the full sample and the two size groups. Therefore, we report the results of the random effects model. In all the three cases, the coefficients on the lagged dependent growth variable are negative and consistently indicate that firm growth adjusts gradually towards convergence. The regression for the full sample shows a significant, negative size impact on firm growth. This evidence refutes Gibrat's Law and reflects the distinguished features of Chinese listed SMEs. Differentiating themselves from large competitors, SMEs tend to have more flexibility in managing increases in the complexity arising from operating, investing, and financing activities and more capacity to adapt themselves to the changing market, so as to find it quicker to capitalize on growth opportunities and easier to overcome obstacles constraining their growth. Their growth is further aided by government policies and the revolutionary transformation of the economy in favor of SME development over the last two decades. Consistent with other studies, the older the firms are, the less likely they are to grow. Business risk is positively related to the firm's post-market growth, supporting our agency argument that lower business risk is counter to firm growth.

We have also identified the opposite effects of state ownership and non-state legal-person shares on firm growth; however, there is no evidence that firm growth is correlated with tradable A-shares. These results are largely consistent with the findings from the recent studies of $\mathrm{Xu}$ and Wang (1999) that examine the effects of ownership structure on firm performance. The firms operating in the capital-intensive industries, in general, experience higher growth rates than those in other industries. Most notably, the role of industry-level innovation and $R \& D$ is modest. The evidence does not provide strong support for most of the previous literature that stresses the role of innovation and R\&D in firm growth. In line with prior expectations, seasoned financing plays a positive role in explaining the growth prospects of Chinese firms. Furthermore, the firms located in the coastal region grow more rapidly than their remote counterparts.

We further group the firms into SMEs and large firms to observe the ways in which the impacts of these factors on firm growth vary with firm size. The results are presented in the second and third columns in Table 5. Firm growth is negatively correlated with firm age, with a similar effect on both groups. Younger SME entrants into the capital market are 
generally the leaders in their own line of business, with strong growth potential, while younger large firms tend to be blue chips with distinct advantages in economies of scale and market power. It is significant that business risk has the opposite effects on SMEs and their large counterparts. Higher business risk augments SME growth, demonstrating that SMEs facing high uncertainty in returns are more likely to exploit growth opportunities. However, the negative effect on large firms, in all likelihood, indicates that agency costs are responsible for low firm growth. Large listed firms in China are majorly owned by the state and operate in the strategic industries, and have historically been a vital instrument for provision of social services, such as employment, housing, medical care, and pensions, and an instrument of state policy, such as stabilization of the national economy. To fulfill their public function, large firms purposely restrain cash flow fluctuations at the expense of firm growth.

As expected, tradable A-shares have negative impacts on firm growth. The negative effect is more substantial in SMEs, suggesting that public shareholders of SMEs bear few duties in monitoring management to ensure that the firm is run in their best interests. Nonstate legal-person shares play a significant role in promoting firm growth of both groups, confirming that the functioning of institutional shareholdings is conducive to developing better monitoring that steers managers in the pursuit of long-run value creation. Consistent with the existing literature on the defects of governmental interference in corporate governance, the state ownership regime has had a detrimental impact on firm growth, and the impact is stronger on large firms than on SMEs. Even though state ownership tends to mean protection for the large firms, as shown in the survival analysis, the negative effect highlights that firms that seek long-term growth need genuinely to improve internal management incentives so that economic activities are better undertaken, instead of relying on external, short-term government support as their last resort.

Further results show that SMEs in the capital-intensive industries, i.e., Manufacturing and Construction, and the service industries, i.e., Transportation and Warehousing, Wholesaling and Retailing Trade, Social Services, and Real Estate experience higher growth rates compared to those in Agriculture and in other industries. The statistical significance of SME growth in Manufacturing and Construction indicates that once SMEs are able to survive in the capital-intensive industries, they have a greater propensity to grow (Doms et al., 1995). 
Moreover, SMEs in Manufacturing produce the daily goods that are most needed and durable products to meet increasing market demand, largely attributable to the expanding domestic market and booming exports, which, in turn, boosts SME growth. The service sector - the fastest growing sector in China since the economic reform in 1979 - provides muchdemanded services for consumers. The greater magnitude of the coefficients on the service industries than on the capital-intensive ones highlights that SMEs find it easier to grow in the expanding service sector than through gaining competitive advantage over their large competitors in the heavy industries that require a higher minimum efficient scale level. The industry effect on SME growth can also be attributable to the government policies in recent years, which aim to create an enabling environment for SMEs in the service industries. This includes widening market access, implementing preferential tax rates and flexibility, channeling funds to the service sector, increasing credit support services, and promoting rational prices for land use, water, gas, and electricity in the service industries (Zhou and Ouyang, 2008). With respect to Transportation and Warehousing, thanks to the government industry policy targeted at transforming traditional transportation and warehousing into the modern logistics industry, this sector is rapidly expanding into new realms by creating added value through the provision of processing and assembly services and enlarged means of transportation for more efficient deliveries. In terms of large firms, industries with heavy fixed assets stand out. Mining, Construction, Utility, and Manufacturing, which are capital intensive and engage in a high level of production, contribute more significantly to the growth of large firms than other industries. The result lends support to Audretsch's (1995) claim that firms which are more capital intensive often grow faster. Notwithstanding this, large firms hold monopoly positions in the strategic industries, i.e., Utility, Construction, and Mining. Not only can they exploit economies of scales and develop cost advantages over millions of minnows, but also they often receive extensive protection and support from the government, given their importance to the national economy.

Most notably, the effect of industry-level innovative high-tech and R\&D is of much less significance for both groups, compared to the other effects on firm growth. This result is seemingly inconsistent with previous studies on the innovation and R\&D effects, but arguably reflects the adverse innovative environment relating to copyright protections that the high-tech industries are facing in China. The large influx of cheap, low quality 
counterfeits and piracy hurts innovative high-tech and R\&D-active firms by limiting the market demand for legitimate products and destroying the goodwill for products that rely on reputation and quality. Although such laws as the Trademark Law, the Patent Law, and the Copyright Law are in place to protect intellectual properties, they are far from complete, leaving the Chinese market to the pirates who fill the void. The enforcement of such laws has been inadequate and ineffective as the standard law enforcement devices and the court system are still subject to bureaucratic administration controls, and have, hence, failed to crack down on counterfeits and tackle piracy. There is more cause to believe that listed SMEs suffer the most from counterfeiting, as nearly one-quarter of SMEs are active in innovative high-tech and R\&D activities (see Table 2). SME brands have to compete with fakes on price, with the fakes normally winning out, since consumers would rather buy counterfeits of SME brands at a cheaper price or buy counterfeits of famous brands at the same price as authentic SME brands. In both circumstances, SMEs either lose potential sales to piracy or are unable to sell enough new products to prosper. The inability to deliver full benefits to innovative high-tech and R\&D-active firms has caused a great deal of disturbance to their full commitment to innovating cutting-edge products and introducing new production practices, which subsequently hobbles their development.

Seasoned financing describing the financing role of the stock market produces striking results. Its contribution to SME growth is minimal and marginally significant $(\beta=0.09)$. This result contrasts with the widely shared perception that equity capital is crucial to SME development (La Porta et al., 1997), indicating that China's equity market plays an insignificant role in sustaining the post-market growth of SMEs. One of the advantages of going public is to gain access to much-needed equity funds. If access is restrained as a consequence of the stringent seasoned issue requirements, listed SMEs are no better positioned than those that remained private in tapping additional channels of finance. Furthermore, inadequate market infrastructure and an inefficient capital market wracked with stock price manipulation and insider trading encourage short-term churn and speculation, thereby rendering stock prices highly volatile and equity finance unstable as a source of external finance. The role of seasoned funds is further undermined by misallocation of gross proceeds. Instead of investing the proceeds in the projects in agreement with the published 
issue prospectuses, many listed firms misappropriate the funds for non-productive purposes or tunnel them to benefit the parent companies (Shirai, 2004). Issuing firms frequently change, without authorization, the use of proceeds specified in the prospectus or do not submit the change to the shareholders' general meeting for approval (Jin et al., 2002). This observation is substantiated by the evidence that seasoned financing has a marginal impact on the growth of large firms too, where managerial discretional behavior over gross proceeds is believed to be substantial, in that the majority of large firms are parent-controlled. These results lead one to conclude that China's capital market has not sufficiently fulfilled the role expected of it as the channel through which firm growth can be sustained.

The results further show that the firms in the coastal region, small or large, experience higher growth rates compared to those in the inner and remote regions, suggesting that preferential policies and strategic measures have had a direct effect on firm growth by creating an environment that is more conducive to production and more responsive to market concerns. In comparison, the remote regions are still handicapped by less favorable locational attributes featured by the usage of traditional production and lack of infrastructure and social and human factors. Although it is a common belief that China has experienced broad-based growth in the course of market economic reform, this study sheds light on the discrepancies and imbalance between regional growth rates, and is qualitatively similar to the previous studies that examine regional inequality (Chen and Fleisher, 1996; Yao and Zhang, 2001). In 2000, the Chinese government launched the "Go West Campaign” and started shifting the focus of economic construction from the coastal region to the inner region and especially to the remote, western region. However, the economy of West China still lags far behind the rest of the nation, and it will take time for the new strategic shift to take effect before the infrastructure, markets, and economic order become well-placed. More notably, the location effect is more significant for SMEs than for their large counterparts in the coastal region, highlighting the importance of the open economic policy in promoting SME development in this region. This is confirmed by the report published by the National Development and Reform Commission on the top 500 growing SMEs in China that SMEs in the coastal regions show much stronger growth opportunities, accounting for 61.81 percent of all the growing SMEs in China. The evidence on the importance of location attributes in firm growth is important from the economic policy perspective. 
Insert Table 5 here.

\section{Conclusion and Policy Implications}

This study uses an integrated approach to examine the dynamics of Chinese listed SMEs with respect to their post-market viability and growth after going public on the basis of national firm-level data. The KM analysis shows that SMEs have a higher risk of evolving to a nonviable state subsequent to market entry, compared to large firms. This study goes on to explore the ways in which the idiosyncratic firm and industry specifics and the underlying financing environment and institutional conditions shape SME dynamics. Three important conclusions follow on from our study. First, SME dynamics are determined by firm specifics. Post-market viability is aided by firm growth and merited by the firm's ability to compete through learning along with age, while post-market growth is constrained by inactivism and free-riding problems associated with a dispersed public ownership structure. The nexus between business risk and SME dynamics supports our cash flow and agency arguments that higher business risk is counter to SME viability but beneficial to SME growth. Second, industry specifics shape the conditions for SME dynamics. SMEs are less likely to remain viable in capital-intensive industries or volatile ones, but once they are able to survive in these industries, they have a greater propensity to grow. Furthermore, SMEs have a strong tendency to remain viable and grow in service industries, largely due to the government policies in support of the service sector in the last two decades. However, the inefficient infrastructure to protect the economic interests of innovative high-tech and R\&D-active firms has deterred these firms from attaining substantial growth. Our results do not support listed SMEs diversifying their business at market entry; instead they should concentrate on the core business. Third, the external business environment is crucial to SME dynamics. Given stringent issue arrangements and agency problems associated with seasoned financing, the capital market is yet to develop into the financing channel through which SMEs are able to thrive. The economic value of location derived from government initiatives for strategic development in the coastal region has become the key source of SME growth in this region. This study fills the significant gap in the literature by identifying the factors that influence firms' post-market transition to either a non-viable state or a growth state in the context of the emerging economies where the market economy has just begun to take hold and the 
institutional infrastructure is far from perfect.

The study raises the issue of seasoned financing that merits policy discussion. The difficulty in raising funds is a long-term bottleneck that hampers the development of SMEs. The majority of SMEs find it too difficult to qualify for initial public offerings on the Main Board or on the SME Board due to the strict criteria for market entry. Their financing environment is worsening, as new evidence from this study suggests that the lack of seasoned funds as a result of stringent issue requirements has hindered those SMEs with growth prospects from developing to their full strength. This argument is supported by the survey conducted by the Shenzhen Stock Exchange in 2006 on seasoned finance practice, reporting that 80 percent of listed SMEs in the questionnaires think that the criteria for seasoned equity offerings are too strict and that the procedures are too lengthy and complicated. It is arguable that more reforms in the capital market may have further limited its role in meeting the demands of SMEs for equity capital. To enable SMEs to fulfill their potential, the CSRC needs to reform the approach to financing the SME sector in several ways. The first is to adopt measures to gradually expand the scale of the SME Board to effectively finance growth-seeking SMEs. Second, to press forward with innovations in seasoned financing. In view of the fact that many SMEs often need ready capital to finance their prosperous projects at affordable costs or to upgrade their products every few years, fast track and more flexible criteria need to be designed in favor of SMEs in an attempt to reduce issue costs and waiting time. For instance, offers and sales of a small quantity of securities that satisfy certain conditions by an issuer, usually an SME, could be exempted from registration procedures. Third, to continue to implement ex ante supervision over seasoned issues and ex post use of issue proceeds. Supervision serves as the lifeline for China's capital markets, especially when the market infrastructure is not properly in place and the vast majority of firms are poorly governed with incomplete internal management and irregular financial operations. Targeted at sustaining SME development, these recommended policies are a necessary complement to the overall reform in promoting a healthy, stable capital market that avails capital to firms at all stages of growth. 


\section{References}

Aaby, Nils E. and Slater, Stanley F. (1989) Management influences on export performance: A review of the empirical literature 1978- 1988. International Marketing Review, 6 (4), pp.7-26.

Acs, Zoltan J. and Audretsch, David B. (1990) Innovation and Small Firms. MIT Press, Cambridge, MA.

Agarwal, Rajshree (1997) Survival of firms over the product life cycle. Southern Economic Journal, 63 (3), pp. 571-84.

Agarwal, Rajshree and Audretsch, David B. (2001) Does entry size matter? The impact of the life cycle and technology on firm survival. Journal of Industrial Economics, 49 (1), pp. 21-43.

Agarwal, Rajshree and Gort, Michael (1996) The evolution of markets and entry, exit and survival of firms. Review of Economics and Statistics, 78 (3), pp. 489-98.

Altman, Edward I. (1983) Corporate Financial Distress. New York: John Wiley \& Son.

Amit, Raphael and Wernerfelt, Birger (1990) Why do firms reduce business risk? The Academy of Management Journal, 33 (3), pp. 20-533.

Anderson, James H., Lee, Young and Murrell, Peter (2000) Competition and privatization amidst weak institutions: Evidence from Mongolia. Economic Inquiry, 38 (4), pp. 527-549.

Anderson, Per K. and Gill, Richard D. (1982) Cox's regression model for counting processes: A large sample study. Annual of Statistics, 10 (4), pp. 1100-1120.

Audretsch, David B. (1991) New firm survival and the technological regime. Review of Economics and Statistics, 73 (3), pp. 441-449.

Audretsch, David B. (1995) Innovation, growth and survival. International Journal of Industrial Organization, 13 (4), pp. 441-458.

Audretsch, David B. and Dohse, Dirk (2007) Location: A Neglected determinant of firm growth. Review of World Economics, 143 (1), pp. 79-107.

Audretsch, David B. and Mahmood, Talat (1995) New firm survival: New results using a hazard function. Review of Economics and Statistics, 77 (1), pp. 97-103.

Audretsch, David B., Santarelli, Enrico and Vivarelli, Marco (1999) Start-up size and industrial dynamics: Some evidence from Italian manufacturing. International Journal of Organization, 17 (7), pp. 965-983.

Bartoloni, Eleonora and Baussola, Maurizio (2009) The persistence of profits, sectoral heterogeneity and firm's characteristics. International Journal of the Economics of Business, 16 (1), pp. 87-111.

Beck, Thorsten., Maksimovic, Vojislav and Demirguc-Kunt, Asli (2002) Financial and legal constraints to firm growth: Does size matter?. World Bank Policy, Research Working Papers; No. WPS 2784.

Berle, Adolf A. and Means, Gardiner C. (1932) The modern corporation and private property, Macmillan, New York.

Bernanke, Ben S. (1983) Nonmonetary effects of the financial crisis in the propagation of the great depression. American Economic Review, 73 (3), pp. 257-76.

Bowman, Edward H. (1980). A risk-return paradox for strategic management. Sloan Management Review, 23 (3), pp. 33-42.

Brito, Paulo and Mello, Antonio S. (1995) Financial constraints and firm post-entry performance. International Journal of Industrial Organization, 13 (4), pp. 543-565.

Carpenter, Robert E. and Petersen, Bruce C. (2002) Is the growth of small firms constrained by internal finance?, The Review of Economics and Statistics, 84 (2), pp. 298-309.

Caselli, Francesco., Esquivel, Gerardo and Lefort, Fernando (1996) Reopening the convergence debate: a new look at cross-country growth empirics. Journal of Economic Growth, 1 (3), pp. 363-389.

Chen, Jian and Fleisher, Belton M. (1996) Regional income inequality and economic growth in China. Journal of Comparative Economics, 22 (2), pp. 141-164.

Child, John (1972) Organizational structure, environment, and performance. Sociology, 6 (1), pp. 2-22.

Christensen, Laurits R. and Caves, Richard E. (1997). Cheap talk and investment rivalry in the pulp and paper industry. Journal of Industrial Economics, 45 (1), pp. 47-73.

Cox, David (1972) Regression models and life tables. Journal of the Royal Statistical Society. Series B (Methodological), 34 (2), pp. 187-220.

Czarnitzki, Dirk and Hottenrott, Hanna (2009) Are local milieus the key to innovation performance? Journal of Regional Science, 49 (1), pp. 81-288.

Doms, Mark., Dunne, Timothy and Roberts, Mark J. (1995) The role of technology use in the survival and growth of manufacturing plants. International Journal of Industrial Organization, 13 (4), pp. 523- 
545.

Driffield, Nigel and Du, Jun (2007) Privatisation, state ownership and productivity: Evidence from China. International Journal of the Economics of Business, 14 (2), pp. 215-239.

Eickelpasch, Alexander., Lejpras, Anna and Stephan, Andreas (2007) Hard and soft locational factors, innovativeness and firm performance: An empirical test of Porter's Diamond model at the micro-level. Discussion papers of DIW Berlin 723, German Institute for Economic Research, DIW Berlin.

Enisan, Akinlo A. and Olufisayo, Akinlo O. (2009) Stock market development and economic growth: Evidence from seven sub-Sahara African countries. Journal of Economics and Business, 61 (2), pp. 162-171.

Evans, David S. (1987) The relationship between firm growth, size, and age: Estimates for 100 Manufacturing Industries. Journal of Industrial Economics, 35 (4), pp. 567-581.

Fama, Eugene F. (1980) Agency problems and the theory of the firm. Journal of Political Economy, 88(2), pp. 288-307.

Fazzari, Steven M., Hubbard, Glenn R. and Peterson, Bruce C. (1988). Financing constraints and corporate investment. Brookings Papers on Economic Activity, 1, pp. 141-195.

González, Natalia U. (2002) Legal environment, capital structure and firm growth: international evidence from industry data. Working Paper 13:02-19, Business Economics Series, Universidad Carlos III de Madrid.

Gort, Michael and Klepper, Steven (1982) Time paths in the diffusion of product innovations. Economic Journal, 92 (367), pp. 630-653.

Grier, Paul and Zychowicz, Edward J. (1994) Institutional investors, corporate discipline, and the role of debt. Journal of Economics and Business, 46 (1), pp. 1-11.

Grossman, Sanford J. and Hart, Oliver D. (1988) One share-one vote and the market for corporate control. Journal of Financial Economics, 20 (1-2), pp. 175-202.

Hansen, Henrik., Rand, John, and Tarp, Finn (2004) SME growth and survival in Vietnam: Did direct government support matter?. University of Copenhagen, Institute of Economics, working paper series.

Hausman, Jerry A. (1978) Specification tests in econometrics. Econometrica, 46 (6), pp. 1251-1271.

Jensen, Michael C. and Meckling, William H. (1976) Theory of the firm: Managerial behaviour, agency costs and ownership structure. Journal of Financial Economics, 3 (), pp. 306-360.

Jin, Shi B., Huang, Ze H., and Lian, Ming H. (2002). The role of warrants in cash offers. Shenzhen Stock Exchange Working Paper 2002 Series.

Jovanovic, Boyan (1982) Selection and the evolution of industry. Econometrica, 50 (3), pp. 649-670.

Kaplan, Edward L. and Meier, Paul (1958) Nonparametric estimation from incomplete observations. Journal of the American Statistical Association, 53 (3), pp. 457-81.

La Porta, Rafael., Lopez-de-Silanes, Florencio., Shleifer, Andrei and Vishny, Robert (1997) Legal determinants of external finance. Journal of Finance, 52 (3), pp. 1131- 1150.

La Porta, Rafael., Lopez-de-Silanes, Florencio., Shleifer, Andrei and Vishny, Robert (1999) Corporate ownership around the world. Journal of Finance, 54 (2), pp. 471-517.

Liedholm, Carl and Mead, Donald C. (1999) Small enterprise and economic development. The role of micro and small enterprises. Routledge Studies in Development Economics. Routledge, London and New York.

Liu, Jia and Pang, Dong (2009) Financial factors and company investment decisions in transitional China. Managerial and Decisions Economics, 30 (2), pp. 91-108.

Mata, Jose., Portugal, Pedro and Guimaraes, Paulo (1995) The survival of new plants: Start-up conditions and post-entry evolution. International Journal of Industrial Organization, 13 (4), pp. 459-481.

Nugent, Jeffrey B. and Yhee, Seung J. (2002) Small and medium enterprises in Korea: Achievements, constraints and policy issues. Small Business Economics, 18 (1-3), pp. 85-120.

Oliveira, Blandina and Fortunato, Adelino (2006) Testing Gibrat's Law: Empirical evidence from a panel of Portuguese manufacturing firms. International Journal of the Economics of Business, 13 (1), pp. 6581.

Peña, Edsel A., Strawderman, Rob and Hollander, Myles (2001) Nonparametric estimation with recurrent event data. Journal of American Statistics Association, 96, pp. 1299-1315.

Persson, Helena (2004) The survival and growth of new establishments in Sweden, 1987-1995. Small Business Economics, 23 (5), pp. 423-440. 
Rasiah, Rajah (2002) Government-business coordination and small enterprise performance in the machine tools sector in Malaysia. Small Business Economics, 18 (1-3), pp. 177-194.

Shirai, Sayuri (2004) Testing the three roles of equity markets in developing countries: The case of China. World Development, 32 (9), pp. 1467-1486.

Shleifer, Andrei (1998) State versus private ownership. Journal of Economic Perspectives, 12 (4), pp. 133-150.

Stiglitz, Joesph E. and Weiss, Andrew (1981) Credit rationing in markets with imperfect information. American Economic Review, 71 (3), pp. 393-410.

Stulz, Rene (1996) Rethinking risk management. Journal of Applied Corporate Finance, 9 (3), pp. 8-24.

Sun, Qian and Tong, Wilson H. S. (2003) China share issue privatization: the extent of its success. Journal of Financial Economics, 70 (2), pp. 183-222.

Sutton, John (1997). Gibrat's legacy. Journal of Economic Literature, 35 (1), pp. 40-59.

Werner, Bönte (2004) Innovation and employment growth in industrial clusters: evidence from aeronautical firms in Germany. International Journal of the Economics of Business, 11 (3), pp. 259-278.

$\mathrm{Xu}, \mathrm{Xiao} \mathrm{N}$. and Wang, Yan (1999) Ownership structure and corporate governance in Chinese stock companies. China Economic Review, 10 (1), pp. 75-98.

Yang, Xing J. (2005). Survival analysis of small and medium-sized firms. Shenzhen Stock Exchange, Working papers series. In Chinese.

Zou, Dong T. and Ouyang, Ri H. (2008) Blue Book of Development and Reform. The Social Sciences Academic Press. In Chinese.

Zingales, Luigi (1998) Survival of the fittest or the fattest? Exit and financing in trucking industry. Journal of Finance, 53 (3), pp. 905-938. 
Table 1. Descriptions of the variables used in the estimations

Variable Definition and coding

\section{Firm specifics}

Firm size

(large firm size: reference size)

Firm age

Post-market growth rate

Business risk

Ownership structure

State ownership

Non-state legal-person

ownership

A-share ownership

Industry specifics

Primary sector

Agriculture

(reference industry)
A firm is classified as a SME if it is officially listed on the SME Board of the Shenzhen Stock Exchange; or 2) if the total number of shares outstanding is less than 200,000,000 shares and the total number of tradable shares outstanding is less than 50,000,000 shares in an individual year; otherwise it is large.

Firm size is coded as 1 if a firm is small and medium-sized, or 0 if it is large.

the life years of a firm in each calendar year since the listing year

annual growth rate in total assets of firm $i$ in year $t$ adjusted by the calendar-year and industry-specific GDP growth index

the standard deviation of residuals in the market model as given by Equation 4

the ratio of state shares consisting of both state shares and state legal-person shares to total shares outstanding of firm $i$ in year $t$

the ratio of non-state legal-person shares to total shares outstanding of firm $i$ in year $t$

the ratio of tradable A-shares to total shares outstanding of firm $i$ in year $t$

any firm within section A (Farming, Forestry, Animal, Husbandry, or Fishery) coded as 1 , or 0 otherwise

Secondary sector (capital-intensive)

Mining

Manufacturing

Utilities

Construction any firm within section B (Mining) coded as 1, or 0 otherwise

any firm within section $\mathrm{C}$ (Manufacturing), except division C5 (Electronics) and division C8 (Medicine and Biological Products), coded as 1, or 0 otherwise

any firm within section $\mathrm{D}$ (Utilities) coded as 1 , or 0 otherwise

any firm within section $\mathrm{E}$ (Construction) coded as 1, or 0 otherwise

Tertiary sector (less capital-incentive)

Transportation and

Warehousing

Wholesale and Retail Trade

Real Estate

Social Services

Communication and Cultural

Industries

Conglomerates

Innovative high-tech and

R\&D sector

\section{External factors}

Seasoned financing

Location

Remote region

(reference region)

Inner region

Coastal region any firm within section $\mathrm{F}$ (Transportation and Warehousing) coded as 1 , or 0 otherwise

any firm within section $\mathrm{H}$ (Wholesale and Retail Trade) coded as 1 , or 0 otherwise any firm within section $\mathrm{J}$ (Real Estate) coded as 1, or 0 otherwise

any firm within section K (Social Services), excluding division K20 (Professional, Scientific Research Services), coded as 1, or 0 otherwise

any firm within section L (Communication and Cultural Industries) coded as 1, or 0 otherwise

any firm within section $\mathrm{M}$ (Conglomerates) coded as 1 , or 0 otherwise

any firm within section G (Information Technology), division C5 (Electronics), division C8 (Medicine and Biological Products) and division K20 (Professional, Scientific Research Services) coded as 1, or 0 otherwise

gross proceeds raised through rights issues, cash offers and convertible bonds over its market capitalization at the accounting year end preceding the issue

A firm is coded as 1 if situated in the remote region, which contains the provinces in the north-western China, that is, Ningxia, Qinghai, Gansu, Inner Mongolia, Tibet and Xinjiang, and those in the south-western China, that is, Guizhou and Yunnan, or 0 otherwise.

A firm is coded as 1 if situated in the inner region, which contains Heilongjiang, Jilin, Shanxi, Shannxi, Henan, Anhui and Jiangxi, or 0 otherwise.

A firm is coded as 1 if situated in the coastal region, which contains Special Economic Zones, 14 open coastal cities and areas, open costal belts, all the capital cities of provinces and autonomous regions and direct-controlled municipalities, or 0 otherwise. 
Table 2. Distributions by industry sector and location for SMEs and large firms

SMEs

No. $(\%)$
Large firms

No. (\%)

\section{Industry sector}

Primary sector

Agriculture

$9(2.35)$

33 (2.78)

Secondary sector (capital-intensive)

Mining
Manufacturing
Utilities
Construction
Sub-total

8 (2.09)

9 (1.83)

$233(60.84)$

Tertiary sector (less capital-incentive)

Transportation and Warehousing

Wholesale and Retail Trade

4 (1.04)

$65 \quad(4.97)$

17 (4.44)

82 (6.23)

Real Estate

7 (1.83)

74 (5.89)

Social Services

9 (2.35)

$36 \quad(3.03)$

Communication and Cultural Industries

3 (0.78)

$11 \quad(0.93)$

12 (3.13)

Conglomerates

89 (23.24)

$70 \quad(5.64)$

Innovative high-tech and R\&D sector

$141(36.81)$

184 (15.49)

Sub-total

501 (42.17)

Total

383 (100)

$1,188 \quad(100)$

\section{Location}

Coastal region

$302(66.25)$

$791(77.84)$

Inner region

57 (24.04)

$287(14.69)$

Remote region

29 (9.72)

$116 \quad(7.47)$

$388 \quad(100)$

$1,194 \quad(100)$

Note: the total number of SMEs and large firms by industry sector and location do not match due to different missing values in each of the categories.

Data source: CSMAR Financial Database, Guo Tai An Information Technology Company Ltd, 2009.

Table 3. Descriptive statistics of the key variables in the estimations

\begin{tabular}{lrcccccc}
\hline & $\begin{array}{c}\text { Age } \\
\text { (year) }\end{array}$ & $\begin{array}{c}\text { Growth } \\
\text { rate }\end{array}$ & $\begin{array}{c}\text { Business } \\
\text { risk }\end{array}$ & $\begin{array}{c}\text { State } \\
\text { shares }\end{array}$ & $\begin{array}{c}\text { Non-state Legal- } \\
\text { person shares }\end{array}$ & A shares & $\begin{array}{c}\text { Seasoned } \\
\text { financing* }\end{array}$ \\
\hline All firms & 8 & 2.937 & 0.741 & 0.293 & 0.232 & 0.345 & 0.047 \\
& $(7.03)$ & $(2.23)$ & $(0.93)$ & $(0.31)$ & $(0.25)$ & $(0.48)$ & $(0.09)$ \\
SMEs & 7 & 3.229 & 0.836 & 0.245 & 0.267 & 0.401 & 0.023 \\
& $(6.15)$ & $(3.06)$ & $(1.16)$ & $(0.22)$ & $(0.34)$ & $(0.36)$ & $(0.06)$ \\
Large firms & 8 & 2.917 & 0.419 & 0.346 & 0.182 & 0.327 & 0.049 \\
& $(8.24)$ & $(3.11)$ & $(0.68)$ & $(0.29)$ & $(0.27)$ & $(0.35)$ & $(0.12)$ \\
\hline
\end{tabular}

The reported values are median values, and standard deviations are presented in parentheses.

Note: a listed firm has more types of ownership than shown in this Table. Therefore, the total percentage of the three types of ownership in the Table is not summed up to $100 \%$.

*: the mean value of seasoned financing is reported, as the median value is zero for both size categories. Just over half of the listed firms have never raised seasoned funds.

Data sources: CSMAR Financial Database, Guo Tai An Information Technology Company Ltd, 2009. 
Figure 1. Kaplan-Meier survival curves for SMEs and large firms

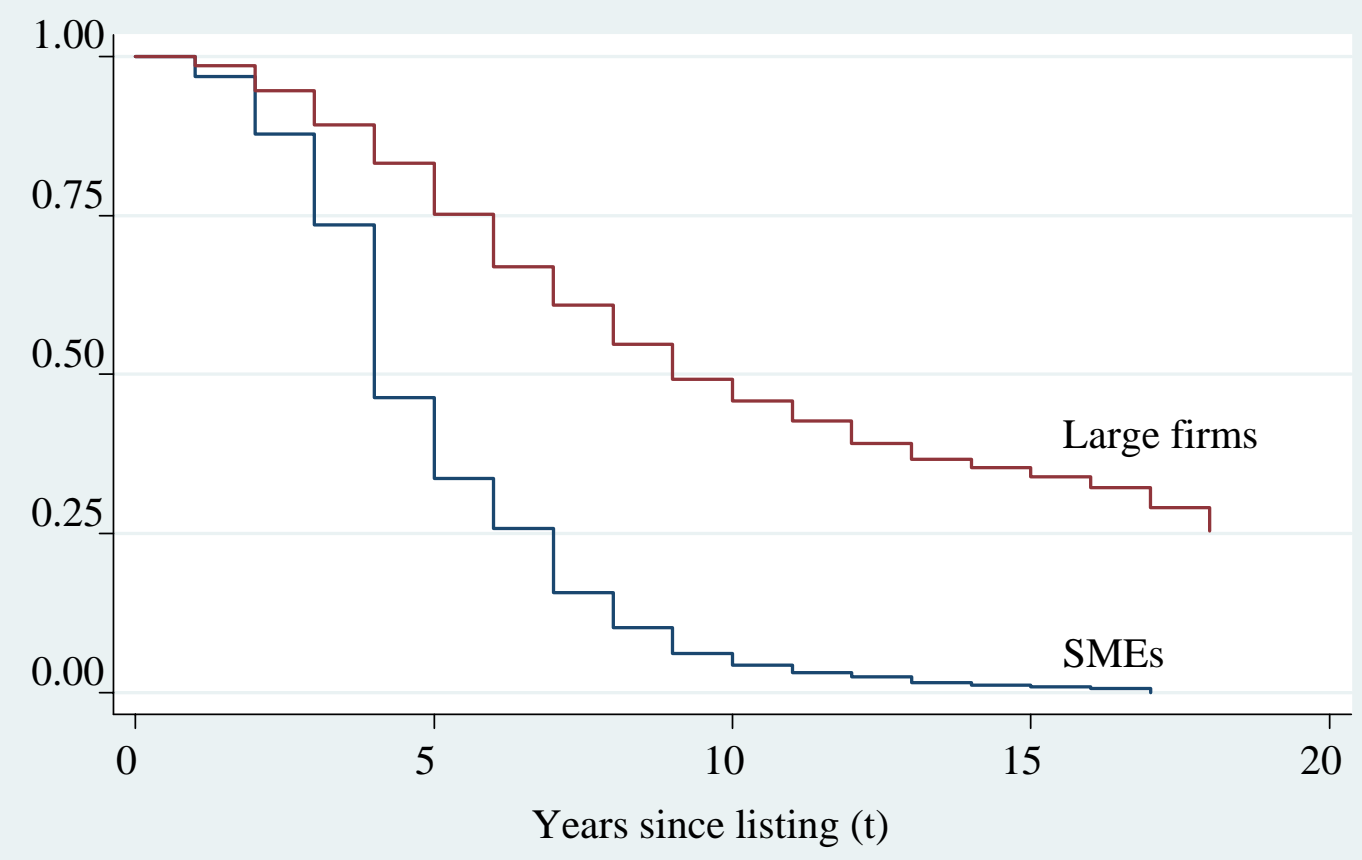

Note: the vertical axis represents the survival rates of firms; the horizontal axis denotes elapsed time in years after the firm is listed on the stock exchange when $t=0$. 
Table 4. Hazard ratio estimation using the Cox-model

\begin{tabular}{|c|c|c|c|}
\hline Explanatory variable & All firms & SMEs & Large firms \\
\hline \multicolumn{4}{|l|}{ Firm specifics } \\
\hline Firm size (large) (reference) & 1 & - & - \\
\hline Firm size (SME) & $1.436^{* * *}$ & - & - \\
\hline Firm age & $\begin{array}{l}0.856^{*} \\
(0.076)\end{array}$ & $\begin{array}{l}0.764^{* *} \\
(0.102)\end{array}$ & $\begin{array}{l}0.941^{*} \\
(0.034)\end{array}$ \\
\hline Post-market growth & $\begin{array}{l}0.663^{*} \\
(0.141)\end{array}$ & $\begin{array}{l}0.484^{* * * *} \\
(0.127)\end{array}$ & $\begin{array}{l}0.616 \\
(0.231)\end{array}$ \\
\hline Business risk & $\begin{array}{l}1.317^{* *} \\
(0.164)\end{array}$ & $\begin{array}{l}1.445^{* * *} \\
(0.199)\end{array}$ & $\begin{array}{l}1.186^{*^{\prime}} \\
(0.107)\end{array}$ \\
\hline State shares & $\begin{array}{l}1.093^{*^{\prime}} \\
(0.056)\end{array}$ & $\begin{array}{l}1.125 \\
(0.146)\end{array}$ & $\begin{array}{l}0.913^{*^{\prime}} \\
(0.047)\end{array}$ \\
\hline Non-state legal-person shares & $\begin{array}{l}0.571^{* *} \\
(0.162)\end{array}$ & $\begin{array}{l}0.535^{* * *} \\
(0.162)\end{array}$ & $\begin{array}{l}0.659^{* * *} \\
(0.203)\end{array}$ \\
\hline A shares & $\begin{array}{l}1.144 \\
(0.309)\end{array}$ & $\begin{array}{l}1.367^{* *} \\
(0.206)\end{array}$ & $\begin{array}{l}1.187^{*^{\prime}} \\
(0.116)\end{array}$ \\
\hline \multicolumn{4}{|l|}{ Industry specifics } \\
\hline Agriculture (reference) & 1 & 1 & 1 \\
\hline Mining and Quarrying & $\begin{array}{l}0.530^{* *} \\
(0.158)\end{array}$ & $\begin{array}{l}1.272^{*} \\
(0.167)\end{array}$ & $\begin{array}{l}0.827^{* *} \\
(0.79)\end{array}$ \\
\hline Manufacturing & $\begin{array}{l}0.454^{* * *} \\
(0.183)\end{array}$ & $\begin{array}{l}1.226^{* * *} \\
(0.127)\end{array}$ & $\begin{array}{l}0.408^{* * * *} \\
(0.161)\end{array}$ \\
\hline Utility & $\begin{array}{l}0.635^{*} \\
(0.155)\end{array}$ & $\begin{array}{l}0.958 \\
(0.264)\end{array}$ & $\begin{array}{l}0.687^{*} \\
(0.135)\end{array}$ \\
\hline Construction & $\begin{array}{l}0.579 \\
(0.253)\end{array}$ & $\begin{array}{l}1.123^{* * *} \\
(0.063)\end{array}$ & $\begin{array}{l}0.634^{*} \\
(0.176)\end{array}$ \\
\hline Transportation and Warehousing & $\begin{array}{l}0.616^{*^{\prime}} \\
(0.172)\end{array}$ & $\begin{array}{l}0.742^{*} \\
(0.117)\end{array}$ & $\begin{array}{l}0.691^{*} \\
(0.148)\end{array}$ \\
\hline Wholesale and Retail Trade & $\begin{array}{l}0.726^{*} \\
(0.121)\end{array}$ & $\begin{array}{l}0.607^{* * *} \\
(0.138)\end{array}$ & $\begin{array}{l}0.673^{* *} \\
(0.132)\end{array}$ \\
\hline Real Estate & $\begin{array}{l}0.746^{*^{\prime}} \\
(0.114)\end{array}$ & $\begin{array}{l}1.215^{* * *} \\
(0.109)\end{array}$ & $\begin{array}{l}0.864^{* * *} \\
(0.055)\end{array}$ \\
\hline Social Services & $\begin{array}{l}0.753 \\
(0.317)\end{array}$ & $\begin{array}{l}0.692^{* * *} \\
(0.127)\end{array}$ & $\begin{array}{l}0.796 \\
(0.139)\end{array}$ \\
\hline Communication and Cultural Industries & $\begin{array}{l}0.959 \\
(0.352)\end{array}$ & $\begin{array}{l}0.814 \\
(0.271)\end{array}$ & $\begin{array}{l}0.783^{*} \\
(0.115)\end{array}$ \\
\hline Conglomerates & $\begin{array}{l}1.258^{*} \\
(0.149)\end{array}$ & $\begin{array}{l}1.383^{* *} \\
(0.227)\end{array}$ & $\begin{array}{l}1.331^{*} \\
(0.208)\end{array}$ \\
\hline High-tech and R\&D & $\begin{array}{l}0.839^{*} \\
(0.088)\end{array}$ & $\begin{array}{l}0.473^{* *} \\
(0.175)\end{array}$ & $\begin{array}{l}0.577^{* *} \\
(0.146)\end{array}$ \\
\hline \multicolumn{4}{|l|}{ External factors } \\
\hline Seasoned financing & $\begin{array}{l}0.877^{*} \\
(0.068)\end{array}$ & $\begin{array}{l}0.422^{* *} \\
(0.173)\end{array}$ & $\begin{array}{l}0.936^{*} \\
(0.037)\end{array}$ \\
\hline Remote region (reference) & 1 & 1 & 1 \\
\hline Inner region & $\begin{array}{l}0.721^{*} \\
(0.126)\end{array}$ & $\begin{array}{l}0.628^{*} \\
(0.165)\end{array}$ & $\begin{array}{l}0.773 \\
(0.215)\end{array}$ \\
\hline Coastal region & $\begin{array}{l}1.158^{*} \\
(0.094)\end{array}$ & $\begin{array}{l}1.254^{* *} \\
(0.142)\end{array}$ & $\begin{array}{l}1.087 \\
(0.122)\end{array}$ \\
\hline $\begin{array}{l}\text { No. of observations (firm years) } \\
\text { Wald test }\end{array}$ & $\begin{array}{l}11,341 \\
\chi_{20}^{2}=606.21 \\
P<0.01\end{array}$ & $\begin{array}{l}3,879 \\
\chi_{19}^{2}=475.34 \\
P<0.01\end{array}$ & $\begin{array}{l}7,462 \\
\chi_{19}^{2}=421.13 \\
P<0.01\end{array}$ \\
\hline
\end{tabular}

Note. The reported values are hazard ratios; robust standard errors are presented in parentheses. $*(* *, * * *)$ denotes rejection of the hypothesis at $10 \%(5 \%, 1 \%)$ significance level. 
Table 5. Random effects model regression on post-market growth

\begin{tabular}{|c|c|c|c|}
\hline Explanatory variable & All firms & SMES & Large firms \\
\hline Lagged growth rate & $\begin{array}{l}-0.096^{* *} \\
(0.046)\end{array}$ & $\begin{array}{l}-0.111^{* * *} \\
(0.035)\end{array}$ & $\begin{array}{l}-0.073^{* * *} \\
(0.039)\end{array}$ \\
\hline \multicolumn{4}{|l|}{ Firm specifics } \\
\hline Firm size (SME) & $\begin{array}{l}-0.473^{* * *} \\
(0.145)\end{array}$ & - & - \\
\hline Firm age & $\begin{array}{l}-0.343^{* *} \\
(0.167)\end{array}$ & $\begin{array}{l}-0.364^{* *} \\
(0.171)\end{array}$ & $\begin{array}{l}-0.351^{*} \\
(0.180)\end{array}$ \\
\hline Business risk & $\begin{array}{l}0.236^{* *} \\
(0.108)\end{array}$ & $\begin{array}{l}0.374^{* *} \\
(0.175)\end{array}$ & $\begin{array}{l}0.229^{*} \\
(0.128)\end{array}$ \\
\hline State shares & $\begin{array}{l}-0.306^{*} \\
(0.161)\end{array}$ & $\begin{array}{l}-0.278^{*} \\
(0.156)\end{array}$ & $\begin{array}{l}-0.386^{* * *} \\
(0.184)\end{array}$ \\
\hline Non-state legal-person shares & $\begin{array}{l}0.322^{* * *} \\
(0.153)\end{array}$ & $\begin{array}{l}0.374^{* *} \\
(0.172)\end{array}$ & $\begin{array}{l}0.366^{*} \\
(0.208)\end{array}$ \\
\hline A shares & $\begin{array}{l}-0.283 \\
(0.194)\end{array}$ & $\begin{array}{l}-0.427^{* * * *} \\
(0.124)\end{array}$ & $\begin{array}{l}-0.313^{*} \\
(0.169)\end{array}$ \\
\hline \multicolumn{4}{|l|}{ Industry specifics } \\
\hline Mining and Quarrying & $\begin{array}{l}0.301^{* *} \\
(0.135)\end{array}$ & $\begin{array}{l}0.146 \\
(0.122)\end{array}$ & $\begin{array}{l}0.378^{* *} \\
(0.182)\end{array}$ \\
\hline Manufacturing & $\begin{array}{l}0.413^{* *} \\
(0.195)\end{array}$ & $\begin{array}{l}0.323^{* *} \\
(0.161)\end{array}$ & $\begin{array}{l}0.207^{*} \\
(0.118)\end{array}$ \\
\hline Utility & $\begin{array}{l}0.307^{*} \\
(0.181)\end{array}$ & $\begin{array}{l}0.289 \\
(0.196)\end{array}$ & $\begin{array}{l}0.357^{* *} \\
(0.174)\end{array}$ \\
\hline Construction & $\begin{array}{l}0.359^{*} \\
(0.201)\end{array}$ & $\begin{array}{l}0.235^{*} \\
(0.139)\end{array}$ & $\begin{array}{l}0.349^{* *} \\
(0.157)\end{array}$ \\
\hline Transportation and Warehousing & $\begin{array}{l}0.418^{* * *} \\
(0.204)\end{array}$ & $\begin{array}{l}0.512^{* * *} \\
(0.243)\end{array}$ & $\begin{array}{l}0.326^{* * *} \\
(0.154)\end{array}$ \\
\hline Wholesale and Retail Trade & $\begin{array}{l}0.367^{*} \\
(0.195)\end{array}$ & $\begin{array}{l}0.479^{* *} \\
(0.235)\end{array}$ & $\begin{array}{l}0.177 \\
(0.145)\end{array}$ \\
\hline Real Estate & $\begin{array}{l}0.156^{*} \\
(0.085)\end{array}$ & $\begin{array}{l}0.368^{*} \\
(0.214)\end{array}$ & $\begin{array}{l}0.187^{*} \\
(0.099)\end{array}$ \\
\hline Social Services & $\begin{array}{l}0.275 \\
(0.212)\end{array}$ & $\begin{array}{l}0.364^{*} \\
(0.186)\end{array}$ & $\begin{array}{l}0.328^{*} \\
(0.173)\end{array}$ \\
\hline Communication and Cultural Industries & $\begin{array}{l}0.325^{* *} \\
(0.154)\end{array}$ & - & $\begin{array}{l}0.341^{* *} \\
(0.166)\end{array}$ \\
\hline Conglomerates & $\begin{array}{l}0.239 \\
(0.162)\end{array}$ & $\begin{array}{l}0.149 \\
(0.151)\end{array}$ & $\begin{array}{l}0.221 \\
(0.143)\end{array}$ \\
\hline Hi-tech and R\&D & $\begin{array}{l}0.149^{*} \\
(0.083)\end{array}$ & $\begin{array}{l}0.135^{*} \\
(0.073)\end{array}$ & $\begin{array}{l}0.151^{*} \\
(0.089)\end{array}$ \\
\hline \multicolumn{4}{|l|}{ External factors } \\
\hline Seasoned financing & $\begin{array}{l}0.127^{*} \\
(0.068)\end{array}$ & $\begin{array}{l}0.094^{*} \\
(0.054)\end{array}$ & $\begin{array}{l}0.112^{*} \\
(0.065)\end{array}$ \\
\hline Inner region & $\begin{array}{l}0.234^{*} \\
(0.132)\end{array}$ & $\begin{array}{l}0.307^{*} \\
(0.181)\end{array}$ & $\begin{array}{l}0.214^{*} \\
(0.119)\end{array}$ \\
\hline Coastal region & $\begin{array}{l}0.418^{* *} \\
(0.203)\end{array}$ & $\begin{array}{l}0.442^{* * *} \\
(0.225)\end{array}$ & $\begin{array}{l}0.378^{* *} \\
(0.192)\end{array}$ \\
\hline $\begin{array}{l}\text { No. of observations (firm years) } \\
\text { Wald test }\end{array}$ & $\begin{array}{l}11,019 \\
\chi_{20}^{2}=287.05 \\
\mathrm{P}<0.01\end{array}$ & $\begin{array}{l}3,673 \\
\chi_{18}^{2}=159.36 \\
P<0.01\end{array}$ & $\begin{array}{l}7,346 \\
\chi_{19}^{2}=252.03 \\
P<0.01\end{array}$ \\
\hline
\end{tabular}

Note. The reported values are regression coefficients. Standard errors are presented in parentheses. $*(* *, * * *)$ denotes rejection of the hypothesis at $10 \%(5 \%, 1 \%)$ significance level.

Large firms, Agriculture and Remote region are used as references in the estimation and not shown in the Table. The dummy variable for Communication and Cultural Industries was dropped from the estimation due to insufficient observations for SMEs. 